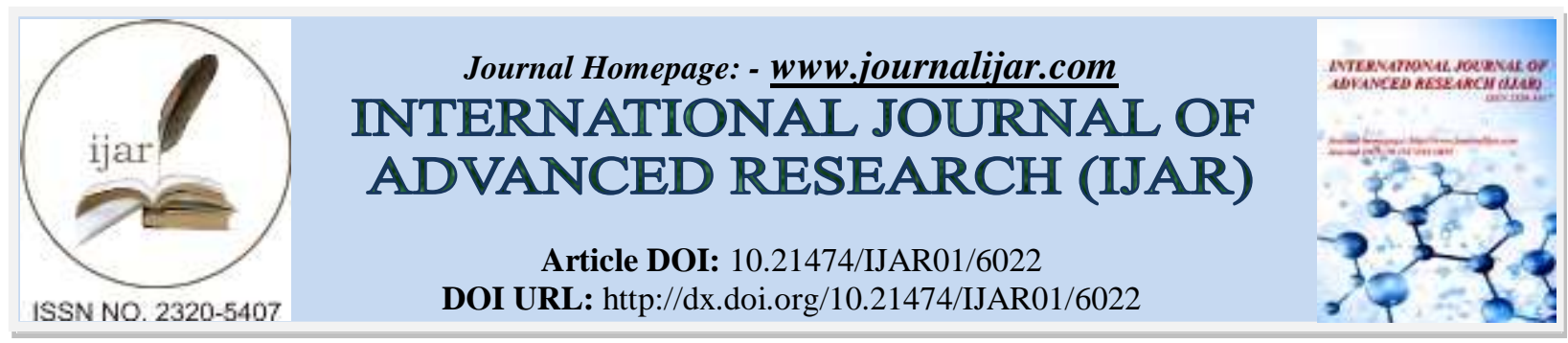

RESEARCH ARTICLE

\title{
EXPERIMENTAL INVESTIGATION ON BRICKS BY REPLACING OF CLAY AND SAND WITH VARIOUS SUPPLEMENTARY MATERIALS.
}

\author{
Kota Sai Krishna and Gujja Swathi. \\ Department of Civil Engineering, Jayamukhi Institute of Technological Sciences, Chennaraopet-506332, India.
}

\section{Manuscript Info}

Manuscript History

Received: 10 October 2017

Final Accepted: 12 November 2017

Published: December 2017

Key words:-

Clay (Alumina), Sand (Silica), Hypo Sludge, Silica Fume, Water absorption, Compressive strength, Bulk density, Efflorescence test.

\section{Abstract}

A brick is major component for building work. Bricks are manufactured by grinding or crushing the clay in mills and mixing it with water to make it plastic. This paper presents a parametric experimental study, by utilization of Hypo Sludge and Silica Fume in brick manufacturing by replaced clay and sand to increase the properties of brick. Silica Fume is taken as constant of 5\% and Hypo Sludge is replaced with $10 \%, 20 \%, 30 \%, 40 \%$ and $50 \%$ for each proportion that have been calculated. The mechanical properties of brick are investigated. These bricks were tested for compressive strength, water absorption, bulk density and efflorescence. The test on brick is according to IS: $3495-1992$.

Copy Right, IJAR, 2017,. All rights reserved.

\section{Introduction:-}

The bricks have been used all over the world in every class and kind of building. If the total bricks produced till today are to be counted, the figure would indeed be astronomical. It is understood that about 65 percent of the bricks in world goes into dwellings and the balance into commercial, industrial and institutional buildings.

The bricks have established as an age old material right from the thatched house to the multi-storeyed buildings. They were initially handmade and used as load bearing material for various structures. With the passage of time and advent of cement and steel, the frames only are filled up with the burnt clay bricks. The production of burnt clay bricks on a scientific and modern basis including proper mining of clays can lead to availability of quality bricks.

In India, the process of brick making has not changed since many centuries except some minor refinements. There have been hardly any efforts in the country to improve the brick-making process for enhancing the quality of bricks. The main reason for this attitude is that the production of bricks has been largely remained confined to the unorganized small sector. Some of the large mechanized brick plants came up in the past but they failed for some reason or other. The result is that the construction industry is largely dependent on the small sector which is unable to deliver high quality bricks in view of rising fuel cost, outdated technology and lower efficiency of production.

In India, bricks are usually made up of clay, and are generally produced in traditional, unorganized small scale industries. Bricks are important building material and about 140 billion bricks are annually produced by these industries. Brick making consumes larger amount of clay which leads to top soil removal and land degradation. Large areas of lands are destroyed every year especially in developing countries due to collection of soil from a depth of about 1 to $2 \mathrm{~m}$ from agricultural land. 
Silica fume is a by-product of producing silicon metal or ferrosilicon alloys. Silica fume has been recognized as a pozzolanic admixture that is effective in greatly enhancing mechanical properties. One of the most beneficial uses for silica fume is in concrete. Because of its chemical and physical properties, it is a very reactive pozzolan. Silica fume consists primarily of amorphous (non-crystalline) silicon dioxide $\left(\mathrm{SiO}_{2}\right)$. The addition of silica fume to concrete improves the latter's durability by reducing permeability and refining pore structure, leading to a reduction in the diffusion of harmful ions and the calcium hydroxide content, resulting in greater resistance to sulfate attack.

Paper making generally produces a large amount of solid waste. Paper fibers can be recycled only a limited number of times before they become too short or weak to make high quality paper. It means that the broken, low- quality paper fibres are separated out to become waste sludge. All the inks, dyes, coatings, pigments, staples and "stickiest" (tape, plastic films, etc.) are also washed off the recycled fibres to join the waste solids. The shiny finish on glossy magazine-type paper is produced using a fine kaolin clay coating, which also becomes solid waste during recycling. This paper mill sludge consumes a large percentage of local landfill space for each and every year. Worse yet, some of the wastes are land spread on cropland as a disposal technique, raising concerns about trace contaminants building up in soil or running of their sludge in incinerators, contributing to our serious air pollution problems. To reduce disposal and pollution problems emanating from these industrial wastes, it is most essential to develop profitable building materials from them. Keeping this in view, investigations were undertaken to produce low cast concrete by blending various ratios of cement with hypo sludge.

Waste may be defined as an unwanted material generated after the manufacturing process of industrial, or from agricultural, or from house hold activity. It is the discarded material which essential requirement of disposal.

Waste causes many nuisances in the environment. It produces many types of viral or bacterial infection for the human and animal which create bed effect on health.

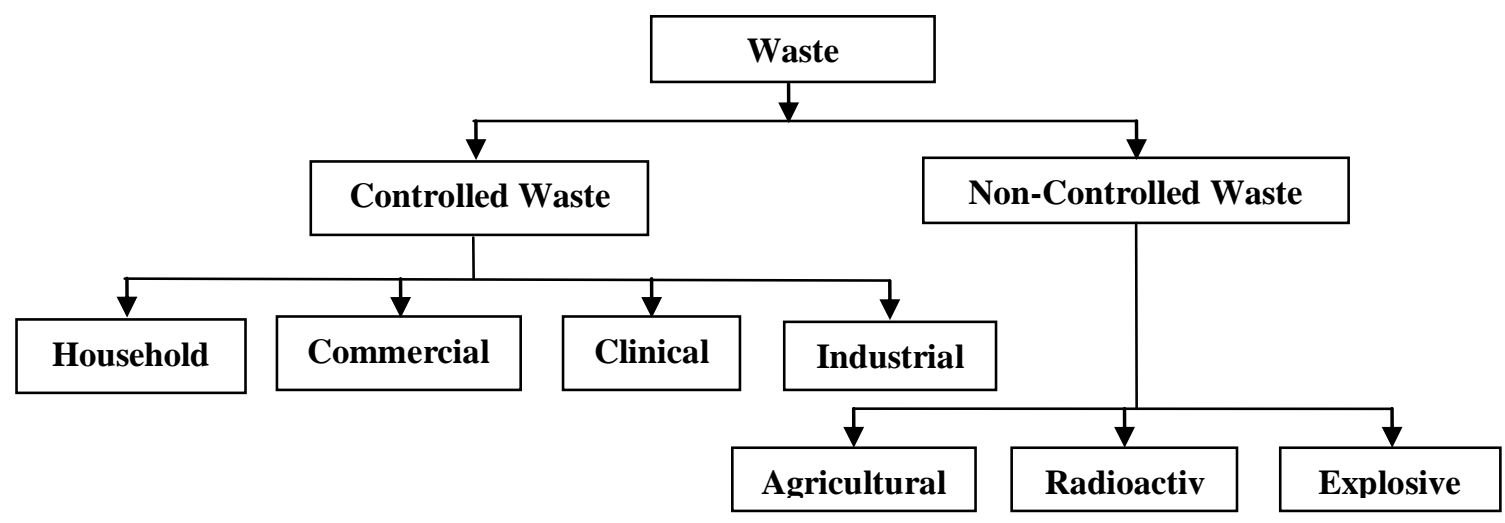

Figure 1:- Classification of Different Types of Waste

\section{Objectives:-}

The major Objective of the project is replacing the costly and scarce conventional building bricks by an innovative and alternative building bricks, which satisfies the following characteristics,

1. Required

2. Cost effective

3. Environmental friendly

4. Less weight

5. Inflammable

6. Less water absorption

7. Easily available

The main objective of this project is optimizing the rice crumb rubber and rice husk ash mix with desirable properties, which satisfies the above mentioned needs. 


\section{Literature Review:-}

Badr El-Din Ezzat Hegazy, Hanan Ahmed Fouad and Ahmed Mohammed Hassanain reported on "Incorporation of water sludge, silica fume, and rice husk ash in brick making". The water sludge is generated from the treatment of water with alum. Disposing of sludge again to the streams raises the concentrations of aluminium oxides in water, which has been linked to Alzheimer's disease. The use of water treatment plant (WTP) sludge in manufacturing of constructional elements achieves both the economical and environmental benefits. Due to the similar mineralogical composition of clay and WTP sludge, this study investigated the complete substitution of brick clay by sludge incorporated with some of the agricultural and industrial wastes, such as rice husk ash (RHA) and silica fume (SF). Three different series of sludge to SF to RHA proportions by weight were tried, which were (25: 50: 25\%), (50: 25: 25\%), and (25: 25: 50\%), respectively. Each brick series was fired at 900, 1000, 1100, and $1200 \mathrm{oC}$. The physical and mechanical properties of the produced bricks were then determined and evaluated according to Egyptian Standard Specifications (E.S.S.) and compared to control clay-brick. From the obtained results, it was concluded that by operating at the temperature commonly practiced in the brick kiln, a mixture consists of $50 \%$ of sludge, $25 \%$ of SF, and $25 \%$ of RHA was the optimum materials proportions to produce brick from water sludge incorporated with SF and RHA. The produced bricks properties were obviously superior to the $100 \%$ clay control-brick and to those available in the Egyptian market.

Vivek Chaudhary and K.S. Gumaste (2015): Rapid urbanization all over the world has resulted in an increase of water and wastewater treatment plant sludge. In cities, sludge disposal by land filling may not be suitable solution now due to land scarcity. In order to sort out the disposal problem of the sludge, sludge management towards the minimization and reutilization of sludge as a useful resource is one of the solutions. Properties of sludge resemble the properties of the construction materials. So, sludge can be utilized as raw material for manufacturing bricks. Moreover in western Maharashtra region, the engineering properties of bricks are not meeting the requirements, as laid by IS code. This Paper reviews the study of various research works that had been done, in order to find the suitable type of sludge for brick manufacturing in western Maharashtra region. This study emphasis on producing bricks manufactured from clay blended with sludge, having properties as per IS code.

Ahmadi et al reported the results of an investigation on the utilization of paper waste sludge obtained from a paper manufacturing industry, as a replacement to the mineral filler material in various concrete mixes. The physical and chemical properties of the waste material were studied. The test results revealed that as the content of the waste increased the water to cement ratio for the mix also increased, since the waste has a high degree of water absorption Therefore, an additional amount of water was required for cement hydration. The results obtained showed that as the amount of the waste increased, the basic strengths, such as compressive strength, decreased.

\section{Materials:-}

Clay: - Clay is the chief ingredient and should contain of 20-30\%. It imparts plasticity to brick earth for easy moulding. It becomes very hard on burning.

Sand: - Sand is a naturally occurring granular material, composed of finely divided rock and mineral particles. The major composition of sand is silica. Natural river sand was used as a fine aggregate. The properties of sand were determined by conducting tests as per IS: 2386 (Part-1). The results are shown in test data of materials. The results obtained from sieve analysis are furnished. The results indicate that the sand conforms to zone 11 of IS: 383-1970.

Hypo Sludge: - Hypo sludge is also known as paper industry waste. It is the by-product of the paper waste. This hypo sludge contains low calcium and minimum amount of silica. Hypo sludge behaves like binding material because of silica and magnesium properties. Hypo sludge may be used as part replacement of Clay and Sand.

Table 1:- Chemical properties of Hypo sludge

\begin{tabular}{|c|c|}
\hline Ingredients & \% in Hypo sludge \\
\hline Moister & 56.80 \\
\hline $\mathrm{CaO}$ & 46.20 \\
\hline $\mathrm{MgO}$ & 3.3 \\
\hline $\mathrm{SiO}_{2}$ & 9.00 \\
\hline $\mathrm{R}_{2} \mathrm{O}_{3}$ & 3.6 \\
\hline Igneous & 27 \\
\hline
\end{tabular}


Silica Fume:- Silica fume particles are extremely small; with more than $95 \%$ of the particles being less than $1 \mu \mathrm{m}$. Particle size is extremely important for both the physical and chemical properties.

Table 2:- Chemical properties of Silica Fume

\begin{tabular}{|c|c|}
\hline Ingredients & \% in Silica Fume \\
\hline $\mathrm{SiO}_{2}$ & 92.08 \\
\hline $\mathrm{Al}_{2} \mathrm{O}_{3}$ & 1.16 \\
\hline $\mathrm{Fe}_{2} \mathrm{O}_{3}$ & 1.24 \\
\hline $\mathrm{CaO}$ & 1.07 \\
\hline $\mathrm{MgO}$ & 0.84 \\
\hline $\mathrm{SO}_{3}$ & 1.27 \\
\hline Igneous & 1.80 \\
\hline
\end{tabular}

Water: - Water is an important ingredient of brick as it actually used for manufacturing of brick. It helps to bind all the raw material for giving proper mix. Water used or making brick should be free from impurities.

Table 3:- Percentage replacement materials

\begin{tabular}{|c|c|c|c|c|c|}
\hline S.No & Type of Brick & Sand & Clay & Hypo Sludge & Silica fume \\
\hline 1. & B1 & 60 & 25 & 10 & 5 \\
\hline 2. & B2 & 55 & 20 & 20 & 5 \\
\hline 3. & B3 & 50 & 15 & 30 & 5 \\
\hline 4. & B4 & 45 & 10 & 40 & 5 \\
\hline 5. & B5 & 40 & 5 & 50 & 5 \\
\hline
\end{tabular}

\section{Methodology:-}

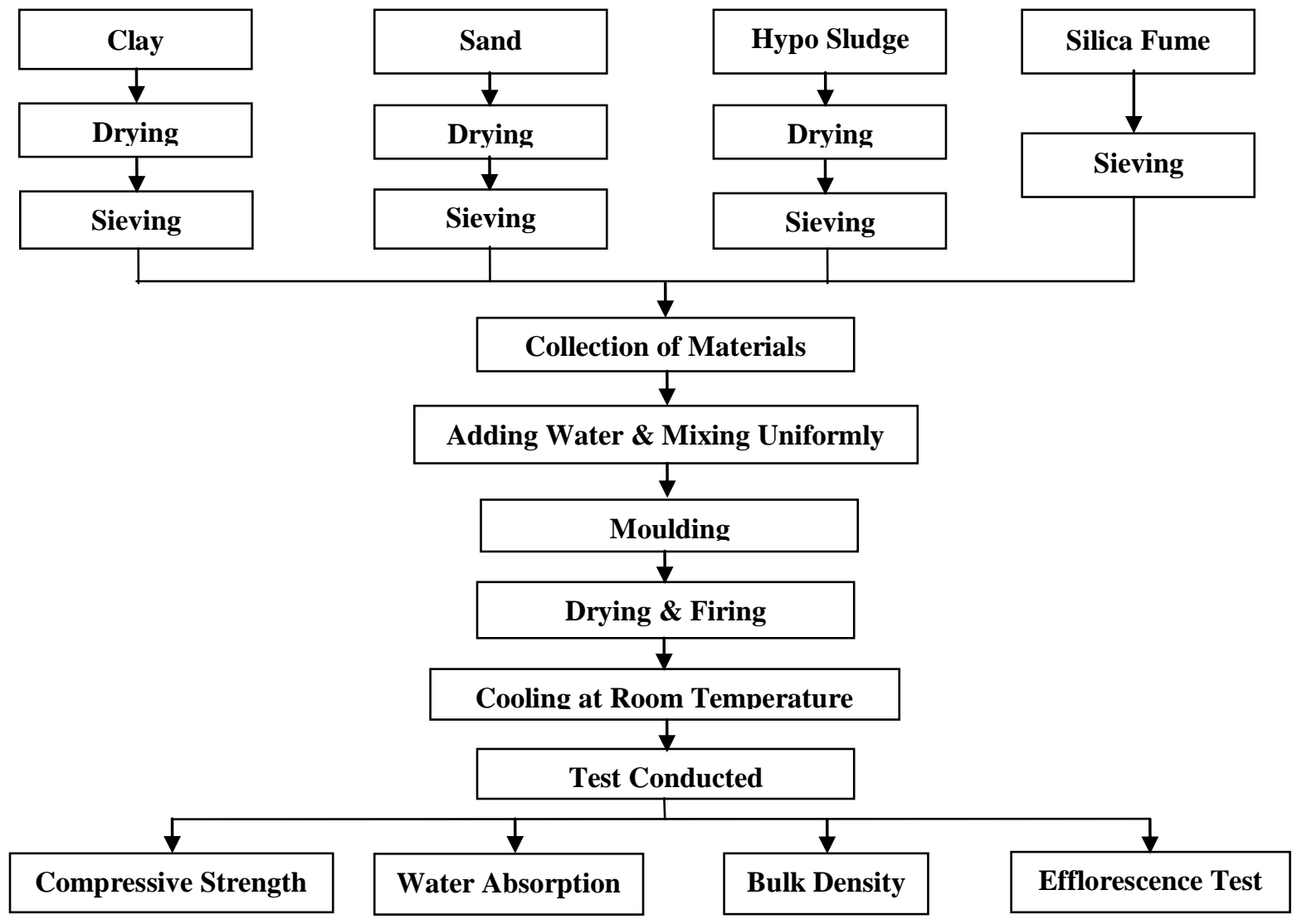

Figure 2:- Methodology 


\section{Results and Discussion:-}

The bricks produced using construction is observed for its various physical characteristics such as colour, shape, size, texture and hardness. The performance is also tested by finding their compressive strength developed, water absorption, bulk density and the effect of efflorescence for mix proportion of bricks. Mould dimension of brick is $(190 X 90 X 90) \mathrm{mm}$. For every mix of sample is taken as three trials. These bricks are dried naturally by sun-light for 14 days and then placed for burning for 2 days. After burning then it is cooled at room temperature for 2 days. The results obtained are discussed in detail in the following sections.

\section{Compressive Strength:-}

Compressive strength of a brick is determined by testing the brick under standard condition using a compressive strength machine. Usually the test is done on three specimens.

$$
\text { Compressive Strength }=\frac{\text { Load at failure }(\mathrm{N})}{\text { Area of bed face }\left(\mathrm{mm}^{2}\right)}
$$

Table 4:- Compressive strength of brick

\begin{tabular}{|c|c|c|c|c|c|}
\hline \multirow{2}{*}{ S.No } & \multirow{2}{*}{ Type of Brick } & \multicolumn{4}{|c|}{ Compressive strength (MPa) } \\
\cline { 2 - 6 } & & Trial-I & Trial-II & Trial-III & Average \\
\hline 1. & B1 & 5.12 & 7.45 & 5.82 & 6.13 \\
\hline 2. & B2 & 6.80 & 7.21 & 8.28 & 7.43 \\
\hline 3. & B3 & 9.82 & 11.44 & 10.45 & 10.57 \\
\hline 4. & B4 & 16.43 & 14.64 & 16.57 & 15.88 \\
\hline 5. & B5 & 15.10 & 12.12 & 14.60 & 13.94 \\
\hline
\end{tabular}

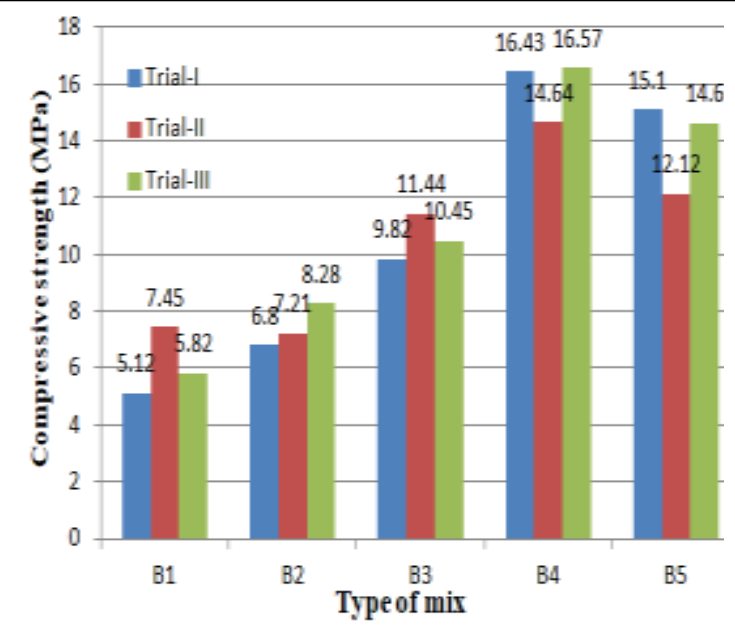

Figure 3:- Compressive strength of type of mix of three trials

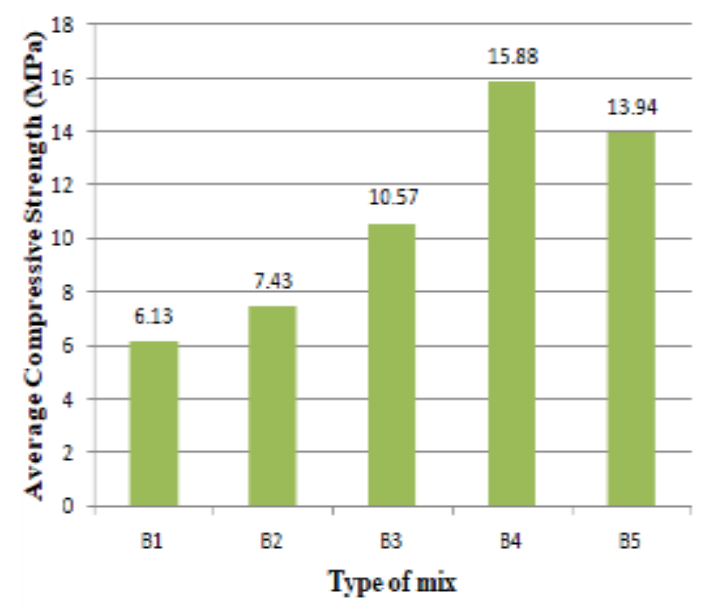

Figure 4:- Average Compressive strength of type of mix of three trials

Water Absorption:- Absorption test is conducted on brick to find out the amount of moisture content absorbed by brick under extreme conditions. In this test, sample dry bricks are taken and weighed. After weighing these bricks are placed in water with full immersing for a period of 24 hours. Then weigh the wet brick and note down its value. The difference between dry and wet brick weights will give the amount of water absorption. For a good quality brick the amount of water absorption should not exceed $20 \%$ of weight of dry brick

$$
\text { Water Absorption }=\frac{\text { wt of brick after removed from water }- \text { wt of brick before immersed in water }}{\text { wt of brick before immersed in water }} X 100
$$


Table 5:- Water absorption of brick

\begin{tabular}{|c|c|c|c|c|c|}
\hline \multirow{2}{*}{ S.No } & \multirow{2}{*}{ Type of mix } & \multicolumn{4}{|c|}{ Water absorption (\%) } \\
\cline { 3 - 6 } & & Trial-I & Trial-II & Trial-III & Average \\
\hline 1. & B1 & 11.3 & 14 & 13.8 & 13 \\
\hline 2. & B2 & 11.6 & 12.8 & 8 & 10.8 \\
\hline 3. & B3 & 6.6 & 7.2 & 10.8 & 8.2 \\
\hline 4. & B4 & 11 & 10.0 & 10.2 & 10.4 \\
\hline 5. & B5 & 13.8 & 14.5 & 14 & 14.1 \\
\hline
\end{tabular}

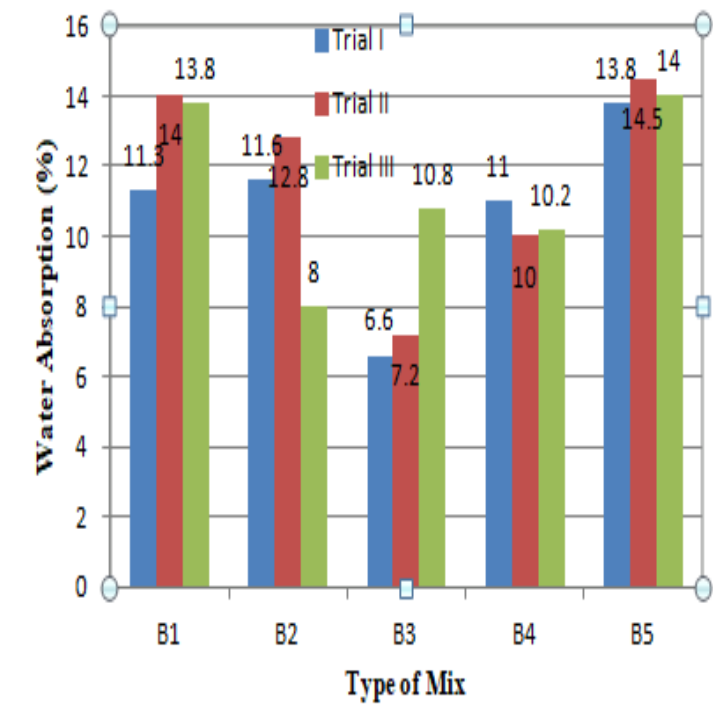

Figure 5: Water absorption of type of mix of three trials

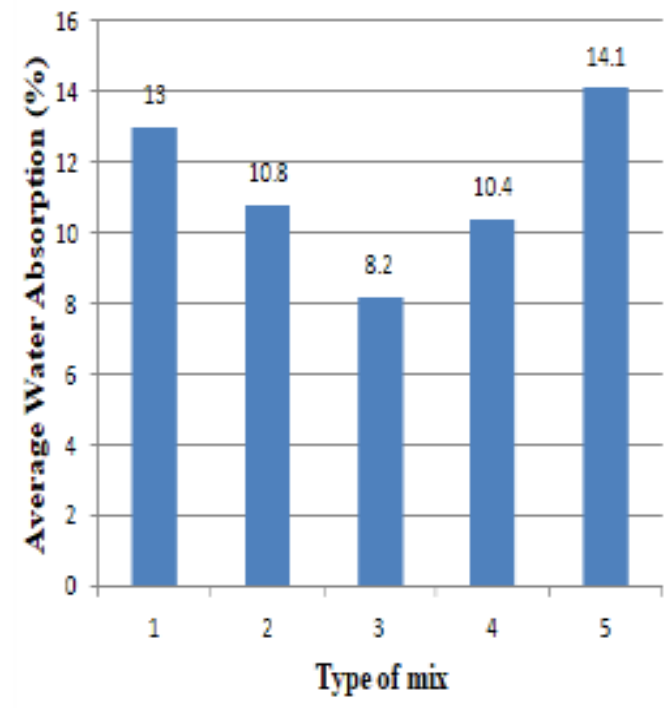

Figure 6: Average water absorption of type of mix of three trials

\section{Bulk Density:-}

The bulk density increased with the increasing amount of clay and hypo sludge as its binding material. When the mixture absorbs more water, the brick exhibits a larger pore size, resulting in a light density. The firing temperature can also affect the particle density of the bricks. The results show that increasing the Sludge content results in a decrease in particle density.

$$
\text { Bulk density }=\frac{\text { mass }(M)}{\operatorname{Volume}(V)}
$$

Table 6:- Bulk density of brick

\begin{tabular}{|c|c|c|c|c|c|}
\hline \multirow{2}{*}{ S.No } & \multirow{2}{*}{ Type of mix } & \multicolumn{4}{|c|}{ Bulk density $\mathbf{( k g / \mathbf { m } ^ { \mathbf { 3 } } )}$} \\
\cline { 3 - 6 } & & Trial-I & Trial-II & Trial-III & Average \\
\hline 1. & B1 & 1856 & 1930 & 1980 & 1922 \\
\hline 2. & B2 & 2444 & 2124 & 2641 & 2403 \\
\hline 3. & B3 & 2210 & 1920 & 2020 & 2050 \\
\hline 4. & B4 & 2490 & 2945 & 2974 & 2803 \\
\hline 5. & B5 & 2600 & 2456 & 2633 & 2563 \\
\hline
\end{tabular}




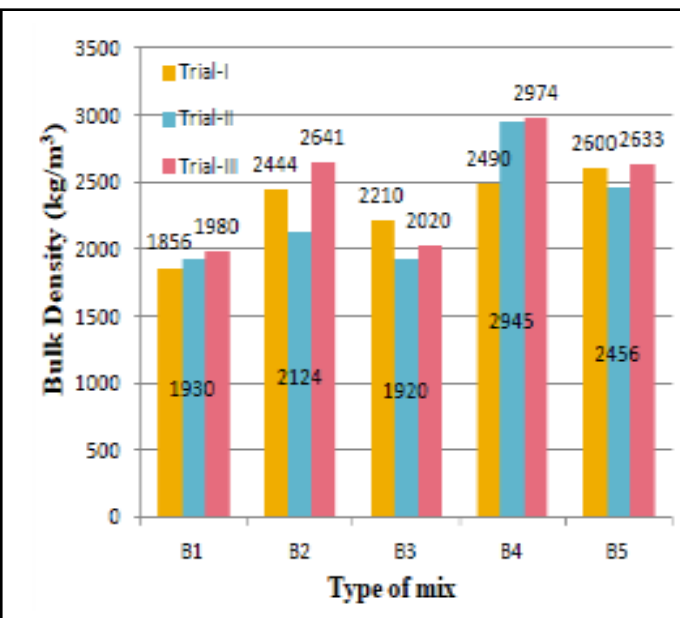

Figure 7: Bulk density of type of mix of three trials

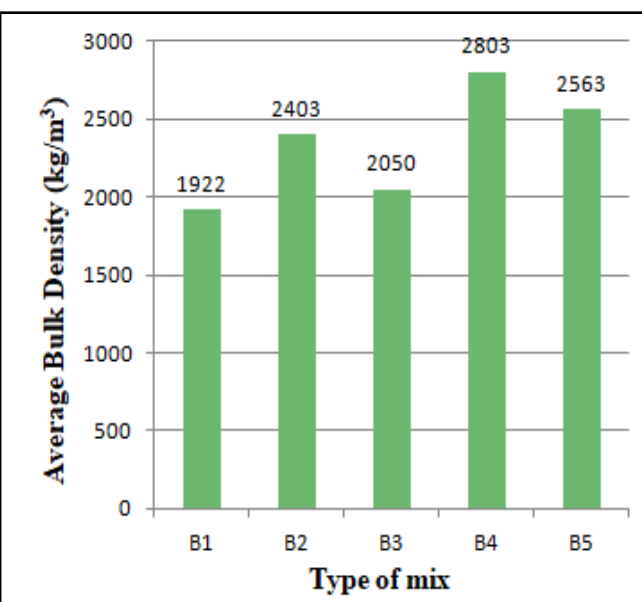

Figure 8: Average Bulk density of type of mix of three trials

Efflorescence:- A good quality brick should not contain any soluble salts in it. If soluble salts are there, then it will cause efflorescence on brick surfaces. To know the presence of soluble salts in a brick, placed it in a water bath for 24 hours and dry it in shade. After drying, observe the brick surface thoroughly. If there is any white or grey colour deposits, then it contains soluble salts and not useful for construction. White or grey patches are due to the presence of sulphate of calcium, magnesium and potassium. These salts will collect on the face of brickwork as an efflorescence (flowering) of white crystals that appear in irregular, unsightly patches.

Table 7:- Efflorescence of brick

\begin{tabular}{|c|c|c|}
\hline S.No & Type of mix & Observation \\
\hline 1. & B1 & Nil \\
\hline 2. & B2 & Nil \\
\hline 3. & B3 & Nil \\
\hline 4. & B 4 & Slight \\
\hline 5. & B5 & Slight \\
\hline
\end{tabular}

\section{Conclusion:-}

In this present experimental investigation work replacing of sand and clay with supplementary materials like hypo sludge and silica fume. The various test conducted and results are concluded at below.

1) The highest compressive strength brick is increased at B4 type of mix $45 \%$ is replacement of sand and clay with $40 \%$ of hypo sludge and $5 \%$ of silica fume, the strength obtain from results 15.88 (MPa). Beyond that it will gradually decrease at B5 type of mix 50\% strength obtain is 13.94 (MPa).

2) The water absorption in present work minimum at $\mathrm{B} 3$ type of mix is $8.2 \%$ and maximum at $\mathrm{B} 5$ type of mix is $14.1 \%$. By observing results the water absorption is increasing by adding of hypo sludge contained.

3) From the results the bulk density of brick is increased at B4 type of mix of $45 \%$ replacement is $2803 \mathrm{~kg} / \mathrm{m}^{3}$.

4) By observing bricks the B1, B2 and B3 there is no white or grey patches it means no soluble salts. Where B4 and B5 are the slightly white or grey patches. Due to calcium present in hypo sludge it increases the white crystal in brick.

5) By replacing hypo sludge and silica fume in bricks it reduces the all aspects of the work. Mainly it reduces the pollution and cost effective. 


\section{References:-}

1. Ashik Kumar Parashar, Rinko Parashar, "Bricks with Total Replacement of Clay by Fly Ash Mixed With Different Materials", International Journal of Scientific and Research Publications, Vol. 2, Issue 7, July 2012.

2. Karaman, S., Gunal, H. and Gokalp, Z. (2012) Variation of Clay Brick Colors and Mechanical Strength as Affected by Different Firing Temperatures. Scientific Research and Essays, 7, 4208-4212.

3. Carter (1982) dealt with the incorporation of ungrounded rice husks into handmade, kiln-fired bricks. Journal of Waste Management and Research.

4. Farrell (2002) Portland cement (PC), Waster paper Sludge Ash (WSA) and Ground Granulated Blast furnace Slag (GGBS). Transactions and Journal of the British Ceramic Society.

5. Ghauri, M.A., Anwar, M.A., Akhtar, N., Haider, R. and Tawab, A. (2009) Status of Coal Biotechnology in Pakistan. Advanced Materials Research, 71-73, 513-516.

6. ASTM C67-17, 2017, Standard Test Methods for Sampling and Testing Brick and Structural Clay Tile, ASTM International, West Conshohocken, PA.

7. R.K. Watile, S.K. Deshmukh, D.W. Gawatre," Performance of Fly ash Interlocking Bricks", International Journal of Civil Engineering \& Technology, Vol. 4, Issue 6, Dec. 2013.

8. Victoria A.N, May 2013. Characterization and performance evaluation of water works sludge as bricks material. International Journal of Engineering and Applied Sciences Vol. 3, No. 3 ISSN2305-8269.

9. Hegazy B.E.E, Fouad H.A, Hassanain A.M. April 24, 2012. Incorporation of water sludge, silica fume, and rice husk ash in brick making. Advances in Environmental Research, Vol. 1, No. 1 (2012) 83-96.

10. Mahapatra P, 2013. Development of acid resistant bricks using waste materials, B Tech NIT Rourkela. $5-16$.

11. Tay, J. H., 1987. Brick manufactured from Sludge, Journal of Environmental Engineering.Vol 113 No. 2. 1-7

12. "Engineering Materials" by R. K. Rajput, S. Chand \& Company Ltd.

13. IS: 1077-1992 "Common burnt clay building bricks".

14. IS: $3495-1992$ (Part 1 to 4) "Methods of tests of burnt clay building brick".

15. IS: 383-1970 "Specification for coarse and Fine Aggregate from Natural Sources for Concrete". 